\title{
Editorial: Puss in Kid Gloves
}

We all know who Plato is, but not many of us know yet what PLATO is. We have been asked to sign and to publicize a manifesto from Philosophy Lecturing and Teaching Opportunities, a charitable scheme designed to promote philosophical activities for the benefit of society as a whole and in particular to protect the interests and use the talents of the 'lost generation' of philosophers who would now be seeking their first jobs in philosophy departments if there were any jobs to seek. PLATO's first specific objective is to raise funds for the support of a number of post-doctoral fellowships at British universities.

PLATO comes hard on the heels of NCP, which used to mean National Car Parks but now also means the National Committee for Philosophy. This is a new specimen of a well known species, a confederation of university departments and other bodies to exert political and propagandist pressure on the Government; the University Grants Committee, the universities and the public in favour of an academic subject and its professional practitioners.

The NCP recognizes that philosophy is much more than an academic subject. Like history and literature and music and archaeology it belongs to the nation and not just to its universities and colleges. Philosophy is more distinctive still than some of these other disciplines, since it is concerned with the foundations and methods of knowledge and enquiry in general and hence with all academic subjects. Its apostles accordingly claim for it special treatment in future university planning and finance. It is widely agreed that reduced resources for classics and oriental studies should be spent more economically by concentrating academic staff and students in a smaller number of larger departments, and the first few mergers are already arranged or are in preparation. Philosophy claims to be a leaven that is needed in every academic lump. Debate continues on whether this necessarily means that there should be an independent department or faculty of philosophy in each university, or whether it would be sufficient to plant philosophic gadflies in a range of other departments to serve as philosophers of this and philosophers of that-science, history, law, education-and as expositors and critics of the philosophical elements in our wider cultural inheritance-Greek philosophy in classical courses, political thought in departments of history and politics, with similar provision for modern languages and English and American studies. 


\section{Editorial}

At its inaugural conference the NCP was already rubbing shoulders with denizens of the corridors of politics and power. The meeting was addressed by $\mathrm{Mr}$ George Walden, Parliamentary Under-Secretary of State for Education, the minister responsible for higher education. His speech seems to have been a success with his audience, and a reader of the text can see why. The minister has come by his own reading and thinking and questioning-with perhaps a little help from some of those Greats-persons who live in corridors-to exemplify the value of philosophy as an ingredient in a wider education. But he did not forget his powers and responsibilities. He reminded the philosophers how plausibly other academics could make matching claims for their own fields, and he reflected on the need for a balance in the distribution of resources between kidney machines and theories of knowledge.

$\mathrm{He}$ also added his ounce of the leaven of humour to what might have been solemn proceedings. His closing quotation came from Kant, who 'amazingly, inexplicably' wrote that 'The class of philosophers is by nature incapable of plotting and lobbying: it is above suspicion of being made up of propagandists'.

Because of the initials of his office, the minister is abbreviated in official documents as PUSS Mr Walden. It must have been a disappointment to some of his more paranoiac listeners, expecting a puss in jackboots, to be confronted with a puss in kid gloves. 